\title{
THE EFFECT OF 3-2-1 STRATEGY ON STUDENTS' READING COMPREHENSION OF THE STUDENTS AT SMA NEGERI 1 BAHOROK
}

\author{
Juliantina \\ Adelia Lestari \\ STKIP Budidaya Binjai
}

\begin{abstract}
Tujuan dari penelitian ini adalah untuk mengetahui apakah ada perbedaan antara siswa yang diajar dengan strategi 3-2-1 dibandingkan dengan teknik konvensional dalam membaca pemahaman pada teks recount pada siswa kelas X SMA Negeri 1 Bahorok. Jenis penelitian yang digunakan adalah penelitian eksperimental. Populasi penelitian ini adalah seluruh siswa kelas X SMA Negeri 1 Bahorok yang terdiri dari 224 siswa yang terbagi dalam tujuh kelas. Kemudian, kelas sampel diambil dengan teknik random sampling. Hasil penelitian menunjukkan bahwa kelas X IPA 1 sebagai kelas eksperimen terdiri dari 35 siswa dan kelas X IPS 1 sebagai kelas kontrol terdiri dari 35 kelas. Dalam mengumpulkan data peneliti menggunakan beberapa pilihan. Tes diberikan kepada kedua kelas dengan topik yang sama. Data dianalisis dengan menggunakan prosedur statistik. T-test digunakan untuk menganalisis skor post-test siswa. Hasil penelitian ini menunjukkan bahwa nilai rata-rata pemahaman membaca siswa di kelas eksperimen $(77,14)$ lebih tinggi daripada skor rata-rata pemahaman membaca siswa di kelas kontrol $(47,71)$. Ini berarti bahwa pemahaman membaca yang diajarkan dengan menggunakan strategi 3-2-1 memberikan perbedaan pada pemahaman membaca siswa. Sedangkan, $t$ hitung $(4,18)$ juga lebih besar dari t tabel $(1,99)$. Itu berarti hipotesis diterima. Dapat disimpulkan bahwa pemahaman membaca yang diajarkan dengan menggunakan strategi 3-2-1 memberikan perbedaan terhadap pemahaman membaca siswa pada siswa kelas X SMA Negeri 1 Bahorok. Jadi, disarankan bagi para guru bahasa Inggris untuk mempertimbangkan penggunaan strategi 3-2-1 sebagai teknik pengajaran membaca pemahaman untuk mendapatkan hasil yang lebih bagus terhadap pemahaman membaca siswa.
\end{abstract}

Key Words: 3-2-1 Strategy, Reading Comprehension, Recount Text

\section{INTRODUCTION}

In learning language, there are four skills that should be mastered by students. These skills are listening, speaking, reading, and writing. Among those four skills, reading becomes one important skill to be mastered. Francois Grellet (1981, p. 8) states that reading is an active skill. It constantly involves guessing, predicting, checking and asking oneself questions. It means that reading is an active process which has interaction between the reader and the writer in which the writer conveyed the information from the text and interprets it into their own language.

The objective of teaching reading in senior high school is the students are expected to understands and comprehend kinds of genre of text, such as, recount, narrative, procedure, descriptive, news item, report, analytical exposition, spoof, hortatory exposition, explanation, and discussion text. So that, in teaching reading, the most important thing that must be achieved by the students is comprehension. 
Carmen Zuniga Dunlap (2007, p. 96) consider although English learners can learn letter-sound relationship and can become good decoders of text, they often tend to struggle with reading comprehension because they lack vocabulary and background knowledge needed to make sense of the text. Reading for comprehension was not an easy task. Based on the researcher's experience most of students at senior high school have some problems related to the reading comprehension skill. They lack of vocabulary, motivation, and knowledge, which make them difficult to understand the meaning, determining the topic and find some more information. These problems made the students not interested to read so they answer questions from a text carelessly.

Moreover the teacher did not apply strategies that can make the students more understand and interested in reading. The lack of strategies in teaching would lead the students become passive readers that will make them difficult to improve their ability in reading comprehension. Sometimes, the teacher only asked the students to read a text and then answer the questions. The teacher did not encourage the students by using appropriate strategies that can make them more interesting in reading. This is also make the students considered that reading was boring activity and made the students achievement in reading were still low. As the factor that was considered having big influence toward students' learning achievement, a teacher who becomes students' facilitator in the classroom should be more creative in teaching reading. They should be carefully in selecting the appropriate teaching strategy, technique or method that can be used in teaching reading that can improve students' interest in reading. The teacher should also be able to create engaging atmosphere by using good strategy in teaching reading comprehension in order to support students' reading success.

\section{3-2-1 Strategy}

The 3-2-1 strategy is a multi-strategy because it involves more than one strategy. It entails creating with Dugan (1997) calls 'Transformational Literature strategies', in which students summarized the main ideas of the text, found the two most important ideas, and share these ideas with their classmates. Finally, the 3-2-1 reading strategy involved training students on recalling what was read by summarizing the three most important points in the text.

The 3-2-1 strategy is a strategy that can be used to help students comprehend what they are reading by summarizing ideas from the text they read. The reason why used this strategy because this strategy allowed students to summarize ideas from the text, in which by 
summarizing ideas from the text the students can determine the main idea and find some more information from the text quickly.

Based on the research background mentioned previously, the research problem was formulated as follow: Is There Effect of using 3-2-1 Strategy on Students' Reading Comprehension of the Tenth Grade Students at SMA Negeri 1 Bahorok in the Academic Year 2018/2019?

\section{METHOD}

The method of this study was experimental research in which the writer tried to expose the effect of 3-2-1 strategy on students' reading comprehension in SMA Negeri 1 Bahorok. Theoretically, this study would focus on proving the strategy that was used whether it is influence or not.

In the design of this study, the writer gave certain treatment to the experimental class to find out the effectiveness of a treatment of a group and can be seen the differences of reading comprehension ability as the result of the differences in treatment used by holding pre-test and post-test to the both classes. In this study, the 3-2-1 strategy was the independent variable which may influence reading comprehension ability as the dependent variable. In this study, there were two groups, namely experimental group and controlled group. The experimental group was a group that would be given treatment by using the 3-2-1 strategy. While, control group was the group that would not be given the treatment by using the 3-2-1 strategy. The writer used pre-test and post-test to the experimental and control group in order to see the effectiveness of using the 3-2-1 strategy by looking the result of pre-test and posttest measurement and comparing the scores between both classes.

The participants of this study were 70 students of SMA Negeri 1 Bahorok selected from 210 students of the tenth grade by random sampling technique. It take 2 classes as the sample up to 70 students. The first class ( X IPA 1) as experimental group and the second class (X IPS 1) as a control group.

The instrument use in this study was multiple choices. It can be objective to measure learning outcome. In this study, the multiple choices consisted of 20 items with four alternative answers. The alternatives include one correct answer and three incorrect answers. The study conducted by using treatment namely the 3-2-1 strategy. The instrument used some reading topic and reading text, the students read the text and they must fill the 3-2-1 strategy chart related to the text they read. 
In collecting the data, the writer used pre-test and post-test. Pre-test consisted of 20 multiple choices. For multiple choice, the correct answer wss given score 5 (five) and incorrect answer was given score 0 (zero). Before giving treatment, the writer gave the pretest to the both classes as sample to know the students' ability in reading comprehension. Post-test consisted of 20 multiple choices. For multiple choice, the correct answer was given score 5 (five) and incorrect answer was given score 0 (zero). This test would administer after the students were given treatments either by using the 3-2-1 strategy or without using the 3-21 strategy to find out the result of different treatment used.

\section{RESEARCH RESULT DAN DISCUSSION}

The writer calculated the data to test the hypothesis whether there is different between students' reading comprehension on recount text in experimental class with 3-2-1 strategy and students' reading comprehension on recount text in control class without 3-2-1 strategy. The writer calculated the data using T-test formula. Two classes were compared, the experimental class was $\mathrm{X}$ variable and the controlled class was $\mathrm{Y}$ variable.

The data was taken from the tenth grade students of SMA Negeri 1 Bahorok. The research showed that the result of the test that was given to the students after teaching process by using 3-2-1 strategy got higher result than the result of the students was taught by using conventional method.

The result of this research showed that the mean score of the experimental group is higher than the mean score of the control group. From the data analysis, the researcher found that the value of t-observe (4.18) was higher than t-table 1.99 at the level significant $5 \%$. So, $\mathrm{Ha}$ is accepted. This is indicated that the use of 3-2-1 strategy has any effect on students' reading comprehension on recount text. The finding indicates that the use of 3-2-1 strategy is proven effective to increase the students' reading comprehension.

\section{CONCLUSIONS}

This research is done to get the empirical data that the 3-2-1 strategy affects the students' reading comprehension ability at the tenth grade students of SMA Negeri 1 Bahorok especially on report text. The conclusions of this research are as follow:

1. The students' reading comprehension ability at the tenth grade students of SMA Negeri 1 Bahorok before applying the 3-2-1 strategy between X IPA 1 as an experimental class and X IPS 1 as a control class are still low. It can be seen from the result of pre-test. In which, 
the lowest score of experimental class is 20 and the highest score is 80 with the mean score pre-test is 58.28 and post-test is 77.14 . While, the lowest score of the control class is 15 and the highest score is 75 . With the mean score of pre-test is 35.42 and post-test 77.71 .

2. There is effect of using the 3-2-1 strategy on students' reading comprehension especially on recount text. In other words, the 3-2-1 strategy is effective to improve the students' reading comprehension especially on recount text. The data shows that the students reading comprehension at the tenth grade students of SMA Negeri 1 Bahorok after applying the 3-2-1 strategy between X IPA 1 as an experimental class and X IPS 1 as a control class is different significantly. It can be seen from the result of post-test score is higher than the result of pre-test. In which the lowest score of the experimental class is 50, and the highest score is 95 with the mean score is 77.41. While, the lowest score of the control class is 30 and the highest score is 75 with the mean score 47.71. According to the result of data calculation, the value of t-observation is bigger than t-table. $t$ bservation $=4.18>$ t-table $=1.99(5 \%)$. So, the alternative hypothesis $(\mathrm{Ha})$ is accepted and the null hypothesis $(\mathrm{Ho})$ is rejected.

\section{REFERENCES}

Arikunto, Suharsimi. Prosedur Penelitian. Rineka Cipta. Jakarta. 2002.

Browne, Ann. A Practical Guide to Teaching Reading in the Early Years. Paul Chapman Publishing. California. 1998.

Grabe, William. Reading in a Second Language: Moving From Theory to Practice. Cambridge University Press. United States of America. 2009.

Purwanto, Ngalim. Psikologi Pendidikan. Romaja Rosdakarya. Bandung. 2013.

Sugiyono. Metode Penelitian Pendidikan. Alfabeta. Bandung. 2017.

Vaughn, Sharon. Sylvia Linan Thompson. Research Based Methods of Reading Instructions Grades K-3. ASDC. United States of America. 2007.

Wainwright, Gordon. How to Read Faster and Recall More Learn the Art of Speed Reading with Maximum Recall. How to Books. Oxfords. 2007.

Zygouris-Coe. Smith. Wiggin. Engaging Students with the Text. International Reading Association. United States of America. 2005. 